ks. Paweł Kaleta

Katolicki Uniwersytet Lubelski Jana Pawła II

\title{
Zasady zawierania umowy dzierżawy w Kodeksie prawa kanonicznego z 1983 roku
}

Swoboda gospodarowania nieruchomościami poprzez dzierżawę daje możliwość nabywania korzyści, zarówno po stronie dzierżawcy, jak i wydzierżawiającego. Dzierżawa, w różnych swych formach, jest obecnie w skali światowej najbardziej rozpowszechnioną obligacyjną formą uzyskiwania przychodów ${ }^{1}$. Obecnie stanowi ona wskazany instrument prawny, szczególnie przy bezpośrednich dopłatach unijnych. Dzierżawa umożliwia dzierżawcom gospodarowanie mieniem i uzyskiwanie z tego tytułu pożytków, bez prawa posiadania własności do użytkowanych gruntów. Umowa dzierżawy należy zatem do swobody umów, o której stanowi art. 3531 kodeksu cywilnego [dalej: k.c. $]^{2}$ : „Strony zawierające umowę mogą ułożyć stosunek prawny według swego uznania, byleby jego treść lub cel nie sprzeciwiały się właściwości (naturze) stosunku, ustawie ani zasadom współżycia społecznego”.

Warto jednak odnotować, że polskie prawo cywilne nie wymaga jakichkolwiek dokumentów dla ważności czy skuteczności zawarcia umowy dzierżawy. Dla ważności jej nie jest wymagana forma pisemna, co oznacza, że strony

I Por. A. Lichowicz, Dzierżawa gruntów rolnych, [w:] Prawo rolne, red. A. Stelmachowski, wyd. 5, Warszawa 2009, s. 187.

2 Ustawa z 23 kwietnia 1964 r. - Kodeks cywilny (Dz.U. z 1964 Nr 16, poz. 93 ze zm.) [dalej: k.c.]. 
mogą zawrzeć umowę w formie ustnej, a nawet przez czynności konkludentne ${ }^{3}$, czyli przez każde zachowanie, które w sposób dostateczny wyraża oświadczenie woli na zewnątrz ${ }^{4}$. Jednakże zawarcie umowy dzierżawy nieruchomości na okres dłuższy niż rok wymaga zachowania formy pisemnej ${ }^{5}$, niedochowanie warunku pisemnej formy umowy nie powoduje nieważności umowy, lecz skutkuje uznaniem umowy za zawartą na czas nieoznaczony (art. 660 k.c.) ${ }^{6}$.

Inaczej jednak przedstawiają się przepisy prawa kanonicznego. Zawarcie umowy dzierżawy jest czynnością nadzwyczajnego zarządzania i należy zachować przepisy o alienacji sensu largo ${ }^{7}$, co oznacza, że na dokonanie takiej czynności konieczna jest zgoda biskupa diecezjalnego. Brak stosownego zezwolenia powoduje niejednolite konsekwencje prawne ${ }^{8}$.

Literatura z prawa kanonicznego w zakresie zawierania umowy dzierżawy nie znalazła dotychczas obszerniejszego opracowania9. Jakkolwiek były podejmowane próby przedstawienia umowy dzierżawy, to jednak koncentrowały się na komentarzach do kan. 1297 i 1298. Celem niniejszego opracowania jest próba odpowiedzi na pytanie: W jaki sposób regulowana jest umowa dzierżawy w świetle prawa kanonicznego? Jakie są warunki dotyczące jej ważności? Poznanie tej dziedziny prawa kanonicznego może stanowić ważny wkład szczególnie dla praktyki zarządców majątku kościelnego.

\section{Pojęcie umowy dzierżawy}

Kodeks Jana Pawła $\mathrm{II}^{10}$ nie definiuje wprost pojęcia dzierżawy. Odnośnie do tego terminu prawodawca kościelny poświęca kan. 1297 i 1298. Doktryna

3 Jest to zgodne porozumienie dwóch stron ustalające ich wzajemne prawa lub obowiązki.

4 B. Rakoczy, Umowa dzierżawy, „Monitor Prawny Proboszcza”, 2012, nr 9, s. 2.

s T. Mróz, Dzierżawa, [w:] Wielka encyklopedia prawa, red. B. Hołyst, Warszawa 2005, s. 175.

6 R. Kubacki, A. Bartosiewicz, Opodatkowanie najmu i dzierżawy, Wrocław 2010, s. 29.

7 Kan. 1295.

8 Szerzej zob. B. Rakoczy, Prawo kanoniczne w orzecznictwie sądów polskich, [w:] Prawo wyznaniowe w Polsce (1989-2009). Analizy - dyskusje - postulaty, red. D. Walencik, Katowice-Bielsko-Biała 2009, s. 275-283.

9 Analiza przedstawianego zagadnienia dotyczy Kościoła katolickiego w Polsce. Z uwagi na fakt, że prawo kanoniczne w umowach o dzierżawę dokonuje kanonizacji przepisów państwowych, zakres prawny został zawężony do systemu prawa polskiego.

Io Codex Iuris Canonici auctoritate Ioannis Pauli PP. II promulgatus, AAS, R. 75, 1983, cz. 2, s. 1-317; Kodeks prawa kanonicznego. Przekład polski zatwierdzony przez Konferen- 
prawa kanonicznego zakres pojęciowy dzierżawy czerpie z prawa cywilnego $^{11}$. Zgodnie z art. $693 \$ 1$ k.c. „Przez umowę dzierżawy wydzierżawiający zobowiązuje się oddać dzierżawcy rzecz do używania i pobierania pożytków przez czas oznaczony lub nieoznaczony, a dzierżawca zobowiązuje się płacić wydzierżawiającemu umówiony czynsz". Umowa dzierżawy należy do umowy wzajemnej ${ }^{12}$, w której wydzierżawiający zobowiązuje się oddać dzierżawcy rzecz lub prawo ${ }^{13}$ do używania pożytków. Warto tu wskazać, że umowa dzierżawy jest niejednokrotnie błędnie interpretowana jako umowa najmu - jako jej synonim. Tymczasem kodeks cywilny zasadniczo odróżnia umowę dzierżawy ${ }^{14}$ od umowy najmu ${ }^{15}$. Różnice wyglądają następująco:

a) przedmiotem dzierżawy obok nieruchomości i ruchomości może być dzierżawa praw ${ }^{16}$, czego nie ma przy umowie najmu;

b) dzierżawca oprócz używania przedmiotu dzierżawy może pobierać pożytki zarówno naturalne, jak i cywilne ${ }^{17}$;

c) w razie braków postanowień umownych w tym względzie, do umów dzierżawy odnoszą się nieco inne przepisy dotyczące czynszu i terminów wypowiedzenia niż w odniesieniu do najmu ${ }^{18}$.

Ponadto umowa dzierżawy jest czynnością prawną odpłatną. Płacenie czynszu przez dzierżawcę jest elementem przedmiotowo istotnym takiej umowy. Nie jest więc dzierżawą umowa, w której, zamiast czynszu, podmiot biorący grunt rolny do używania i pobierania pożyków zobowiązuje się tylko do płacenia

cję Episkopatu Polski, Poznań 1984.

II Por. Kan. 1290. Zob. J. Mantecón, Comentario c. 1297, [w:] Comentario exegético al Códico de Derecho Canónico, red. A. Marzoa, J. Miras, R. Rodríguez-Ocaña, vol. 4/1, Pamplona 2002, s. 170.

${ }_{12}$ Umowa dzierżawy mieściła się prawie rzymskim jako umowa konsensualna zwana locatio - conductio. Zob. W. Rozwadowski, Tradycje rzymskie w polskim prawie cywilnym, [w:] System prawa prywatnego. Prawo cywilne - część ogólna, red. M. Safjan, t. 1, Warszawa 2007, s. 19.

13 Art. 709 k.c. zob. J. Panowicz-Lipska, Najem, [w:] Prawo zobowiazań - część szczegótowa, red. J. Panowicz-Lipska, t. 8, Warszawa 2011, s. 98.

I4 Art. 693-709 k.c.

is Art. 659-692 k.c.

16 Co do dzierżawy praw stosuje się odpowiednio przepisy o dzierżawie rzeczy art. 709 k.c.

${ }_{17}$ Art. 53 k.c. zob. Z. Radwański, J. Panowicz-Lipska, Zobowiązania-część szczegółowa, wyd. 9, Warszawa 2012, s. 156.

I8 Art. 667 k.c. w związku z art. 694 k.c. Por. W. Siuda, Elementy prawa dla ekonomistów, Poznań 2009, s. 264. 
podatków i innych ciężarów związanych z posiadaniem gruntu. Do takiego stosunku przepisy o dzierżawie mogą być stosowane tylko w drodze analogii ${ }^{19}$.

Należy podkreślić, że dzierżawa jest stosunkowo łatwym sposobem zagospodarowania nieużytków należących do kościelnej osoby prawnej. Jednak w zawieraniu umów dzierżawy doktryna prawa kanonicznego stosuje przepisy o alienacji (kan. 1291-1294) ${ }^{20}$. Przy czym trudno jest zgodzić się, aby umowa dzierżawy była alienacją sensu stricto, ponieważ zgodnie z doktryną nie jest ona przeniesieniem prawa własności (czyli dominium directum), lecz jest przeniesieniem prawa używania ${ }^{21}$. Jednak z uwagi na skutek uboczny, jakim jest ryzyko poważnych strat bądź możliwość pogorszenia się sytuacji majątkowej kościelnej osoby prawnej (np. długoterminowe umowy o dzierżawę, niewywiązanie się z umów), prawodawca taką czynność zakwalifikował jako alienację sensu largo ${ }^{22}$. W tym przypadku zastosowanie ma kan. 1295, który stanowi lex specialis aktów nadzwyczajnego zarządzania. Podobną wykładnię stanowił kodeks pio-benedyktyński, zgodnie z którym umowa dzierżawy wieczystej (emfiteuza) czy najmu (locatio), która przekracza okres 9 lat, była równoznaczna z alienacją sensu largo i należało zachować przepisy dotyczące alienacji ${ }^{23}$.

W obowiązującym Kodeksie prawa kanonicznego prawodawca kościelny z uwagi na różnorodność sytuacji w poszczególnych krajach ${ }^{24}$, jak i na konieczność oparcia się w prawie cywilnym, upoważnił Konferencję Episkopatu - zgodnie z kan. 1297 - by ustanowiła normy dotyczące dzierżawy dóbr kościelnych, zwłaszcza zaś konieczności uzyskania zgody ze strony kompetentnej władzy kościelnej. Wspomniany wymóg uzyskania zgody stanowi naturalną konsekwencję ochrony majątku kościelnego, aby ten nie znalazł

I9 J. Nadler, Komentarz art. 693 k.c., [w:] Kodeks cywilny. Komentarz, red. E. Gniewek, P. Machnikowski, wyd. 5, Warszawa 2013, s. 1217.

$2 \circ$ Zob. Konferencja Episkopatu Polski, Instrukcja Konferencji Episkopatu Polski w sprawie zarządzania kościelnymi dobrami materialnymi, pkt 2.9. Dokument niepublikowany.

2I Szerzej zob. B. Tańska-Hus, Dzierżawa jako podstawowy instrument prawny przeksztatceń wtasnościowych i strukturalnych $w$ rolnictwie państwowym na Dolnym Ślasku, „Roczniki Akademii Rolniczej w Poznaniu”, 1999, nr 53, s. 293-303.

22 J. Mantecón, Comentario c. 1297, dz. cyt., s. 170.

23 F. Bączkowicz, Prawo kanoniczne. Podręcznik dla duchowieństwa, t. 2, Opole 1958, s. 577.

${ }_{24}$ Zob. T. Paprocki, Recent Developments Concerning Temporal Goods, „Proceeding of the Cannon Law Society of America”, 2009, nr 2, s. 257-284. 
się w gorszej sytuacji ${ }^{25}$. Dodać należy, że wymóg ten nie dotyczy dzierżawy o bardzo małej wartości ${ }^{26}$.

Warto w tym względzie wskazać, że z kan. 1297 korensponduje również kan. 1277 in fine: „Konferencja Episkopatu Polski powinna określić, które akty należy zaliczyć do nadzwyczajnego zarządzania”. Wówczas opracowane normy obowiązywałyby ad validatem tylko w sprawie ceny przekraczającej ustaloną górną granicę lub dzierżawy rzeczy, które z uwagi na swą naturę lub wartość angażowałyby w znaczący sposób majątek kościelny ${ }^{27}$. Jednak jak dotąd (do 2013 roku) Konferencja Episkopatu Polski nie określiła, które akty należy zaliczyć do nadzwyczajnego zarządzania ${ }^{28}$. W takim przypadku w mocy należy zachować prawo statutowe konkretnej osoby prawnej, a w razie gdyby ich nie było, zgodnie z kan. $1281 \$ 2$ biskup diecezjalny po wysłuchaniu zdania rady do spraw ekonomicznych powinien określić tego rodzaju czynności w odniesieniu do podległych mu osób prawnych. Ponadto z przepisem tym wiąże się kan. 1276, który stanowi, że do kompetencji ordynariusza należy czuwać, aby nie wkradły się nadużcia w zarządzie wszystkimi dobrami należącymi do podległych mu osób prawnych ${ }^{29}$.

\section{Warunki umowy dzierżawy w Kodeksie prawa kanonicznego z 1983 roku}

Z uwagi na stałość celów, którym służy mienie kościelne, sam majątek kościelny i prawa z tym związane podlegają ochronie. Zatem, co do zasady,

25 J. P. Schouppe, Derecho patrimonial canónico, Pamplona 2007, s. 92.

${ }_{26}$ Kan. 1298 in principio. Zob. P. V. Pinto, Commento al codice di dirito canonico, wyd. 2, Vatican 2001, s. 746.

${ }_{27}$ M. L. Alarcón, Dobra doczesne Kościoła, [w:] Kodeks prawa kanonicznego. Komentarz, red. P. Majer, Kraków 2011, s. 971.

28 Dla porównania Konferencja Amerykańskich Biskupów Katolickich dzierżawy krótkoterminowe związała z przepisami nadzwyczajnego zarządzania kan. 1277, natomiast długoterminowe określiła jako akty związane z alienacją sensu largo kan. 1295, zob. R. T. Kennedy, Book V. The Temporal Goods of the Church, [w:] New Commentary on the Code of Canon Law, red. J. P. Beal, J. A. Coriden, T. J. Green, New York-Mahwah 2000, s. 1507.

29 Congregatio pro Episcopis, Direttorio Apostolorum Successores per il ministero pastorale dei vescovi, Libreria Editrice Vaticana 2004; Kongregacja ds. Biskupów, Dyrektorium Apostolorum successores o pasterskiej posłudze biskupów, 22 II 2004, [w:] Ustrój hierarchiczny Kościoła. Wybór źródet, red. W. Kacprzyk, M. Sitarz, Lublin 2006, s. 517-711, art. 189. 
majątku kościelnego nie wolno sprzedawać lub wydzierżawiać ich zarządcom albo krewnym lub powinowantym zarządców, aż do czwartego stopnia ${ }^{30}$. Mając to na uwadze, prawodawca okreslił warunki dotyczące ważności, jak i godziwości, które należy zachować przy dokonywaniu aktów związanych $\mathrm{z}$ alienacją, do których również należy zawarcie umowy dzierżawy. Poniżej zostaną przedstawione warunki określone przez Kodeks prawa kanonicznego. Natomiast w dalszej części artykułu zostaną przedstawione wybrane normy prawa partykularnego, które w tym względzie stanowią uszczegółowienie norm prawa powszechnego oraz jego dostosowanie do warunków, w których funkcjonuje konkretny kościół diecezjalny.

\subsection{Warunki zawarcia umowy dzierżawy ad validatem}

Majątek kościelnej osoby prawnej jest chroniony prawem. Chcąc ważnie zawrzeć umowę dzierżawy, należy zachować normy prawa kanonicznego zawarte w kan. 1291-1295. W doktrynie prawa kanonicznego wyróżnia się następujące warunki dotyczące ważności aktu związanego z alienacją:

\section{a. Zachowanie wymogów prawa państwowego}

Prawo kanoniczne odnośnie do umowy dzierżawy, zgodnie z kan. 1290, kanonizuje ${ }^{31}$ przepisy prawa cywilnego i uznaje je za własne z tymi samymi skutkami, chyba że przepisy te sprzeciwiają się prawu Bożemu lub co innego zastrzega prawa kanoniczne ${ }^{32}$. W przypadku umów o dzierżawę podstawę prawa cywilnego stanowi kodeks cywilny, art. 693-709.

3o Kan. 1298. Zgodnie z kan. $108 \$ 1$. Pokrewieństwo oblicza się poprzez linie i stopnie; $\$ 2$. W linii prostej tyle jest stopni, ile zrodzeń, czyli osób, nie licząc przodka. $\$ 3$. W linii bocznej jest tyle stopni, ile jest osób w obydwu razem liniach, nie licząc przodka.

${ }^{31}$ Zjawisko to dotyczy sytuacji, w której prawo kanoniczne nie reguluje pewnej materii będącej w jego kompetencji, lecz nakazuje stosowanie całościowe lub częściowe prawa cywilnego. Normy prawa cywilnego stają się formalnie normami własnymi prawa kościelnego. Zob. P. Ciprotti, Le leggi civili. Nel Nuovo Codice didiritto canonico, „Ephemerides Iuris Canonici”, 1983, nr 39, s. 189-202.

32 Zob. Kan. 22; L. Chiappetta, Il Codice di Diritto Canonico. Commento giuridico-pastorale, t. 2, Bologna 2011, s. 599; zob. J. Renken, The Collaboration of Canon Law and Civil Law in Church Property Issues, „Studies in Church Law”, 2008, nr 4, s. 43-82. 


\section{b. Uzyskanie zgody kompetentnej władzy}

W celu ważnego zawarcia umowy dzierżawy, należy uprzednio uzyskać pisemną zgodę kompetentnej władzy. Zastosowanie mają tu kan. 1297, 1291 oraz $1292 \$ 1$. Przy czym żaden z nich nie stawia wymogu, aby zgoda ta została wydana na pismie. Jednak z uwagi na to, że działanie to ma charakter aktu administracyjnego oraz dotyczy zakresu zewnętrznego, w związku z kan. 37, akt prawny powinien zostać wydany na piśmie. Wykładnię tę powterdza kan. $1281 \$ 1$, który stanowi, że „zarządcy nieważnie wykonują czynności, które przekraczają granice i sposób zwyczajnego zarządzania, jeśli nie uzyskali wcześniej pisemnego upoważnienia od ordynariusza" ${ }^{33}$. Skoro przepis ten dotyczy aktów nadzwyczajnego zarządzania, wydaje się słuszny postulat, by pisemne zezwolenie dotyczyło alienacji, chociaż kan. $1292 \$ 1$ o zezwoleniu w piesemnej formie wprost nie wspomina. Dopiero jednoznaczną odpowiedź odnaleźć można w kan. 1298, który odnośnie do zawarcia umowy dzierżawy stawia wymóg pisemnego zezwolenia kompetentnej władzy. Wniosek ten potwierdza Instrukcja KEP w sprawie zarzadzania kościelnymi dobrami materialnymi: „Jeśli umowa dzierżawy ma obowiązywać ponad dwa lata, wymagana jest uprzednia pisemna zgoda biskupa diecezjalnego"34.

Pozostaje więc zatem określić zakres kompetentnej władzy kościelnej, o której stanowi prawodawca w kan. 1297. I tak:

a. Kompetentną władzą dla podległych sobie osób prawnych jest biskup diecezjalny ${ }^{35}$, jeśli wartość dóbr mieści się między sumą największą i sumą najniższą wyznaczoną przez Konferencję Episkopatu ${ }^{36}$. W przypadku gdy wartość rzeczy alienowanej (podlegającej temuż biskupowi), przekracza naj-

\footnotetext{
33 Kan. $1281 \S 1$.

34 Pkt 3. 17. Dla porównania Konferencja Episkopatu Francji wprowadziła przepis, że każda dzierżawa trwająca dłużej niż 3 miesiące musi uzyskać uprzednio zgodę biskupa. Por. L. de Echeverria, Commentateur c. 1297, [w:] Code de dront Canonique annoté, red. J. P. Durand, Paris 1989, s. 705.

$35 \quad$ Kan. $1292 \$ 1$.

36 Konferencja Episkopatu Polski zgodnie z kan. $1292 \$ 2$ ustaliła równowartość $100000 €$ (sto tysięcy euro) jako summa minima alienacji, natomiast $1000000 €$ (milion euro) jako summa maxima alienacji. Dekret Kongregacji ds. Biskupów (05.12.2006) zawierajacy recognitio decyzji Konferencji Episkopatu Polski w sprawie nowych sum (minimalnej i maksymalnej) w związku z alienacją dóbr kościelnych, „Akta Konferencji Episkopatu Polski”, 2007, nr 13, s. 33.
} 
wyższą sumę wyznaczoną przez Konferencję Episkopatu, lub jeśli chodzi o rzeczy darowane Kościołowi na mocy ślubu (ex voto), czy też rzeczy kosztowne z powodów historycznych lub artystycznych, wymagane jest ponadto zezwolenie Stolicy Apostolskiej ${ }^{37}$.

b. W przypadku dóbr publicznych osób prawnych niepodlegających biskupowi diecezjalnemu kompetentną władzę wyznaczają ich własne statuty ${ }^{38}$.

c. Dobra instytutów życia konsekrowanego podlegają właściwym przepisom zgodnie z kan. $638 \$ 3$.

d. Natomiast dobra prywatnych osób prawnych regulowane są przez ich własne statuty ${ }^{39}$.

Brak uprzedniej zgody biskupa diecezjalnego na akty związane z alienacją, zgodnie z ostatnią judykaturą stanowią o czynności prawnej niezupełnej (art. 63 k.c.), jest to tzw. czynność prawna kulejąca (negotium claudicans). Do takiego wniosku doszedł Sąd Najwyższy w wyroku z 19 grudnia 2008 roku sygn. akt III CZP 122/08 ${ }^{40}$, który uznał, że „Sprzedaż nieruchomości przez kościelną osobę prawną osobie świeckiej, bez wymaganego w prawie kanonicznym zezwolenia właściwej władzy kościelnej, stanowi bezskuteczność zawieszoną" ${ }^{31}$. Podobny wyrok sformułował Sąd Apelacyjny w Poznaniu w wyroku z 26 maja 2011 roku sygn. akt I ACa 356/1 1², który przyjął „statutową" naturę prawa kanonicznego i uznał, że brak zgody właściwych władz kościelnych na dokonanie czynności prawnej przez kościelną osobę prawną stanowi czynność prawną kulejącą (negotium claudicans) ${ }^{43}$. Biorąc pod uwagę odpowiedzialność za podejmowanie takich czynności, trzeba

37 Kan. $1292 \$ 2$.

${ }_{38}$ Kan. $1292 \$ 1$.Zob. H. Pree, Genehmigungspflichten in der pfarrlichen vermögensverwaltung. Eine universal rechtliche perspective, „Archiv für katholisches Kirchenrecht”, 2008, nr 177, s. 502-523.

39 Kan. $1257 \$ 2$.

40 „Biuletyn Sądu Najwyższego”, 2008, nr 12, poz. 7.

${ }^{4 I}$ Zob. glosy do tej uchwały: J. Kuźmicka-Sulikowska, P. Machnikowski, Glosa, „Orzecznictwo Sądów Polskich”, 2010, nr 2, s. 120-126; A. Januchowski, Glosa, „Orzecznictwo Sądów Polskich”, 2010, nr 2, s. 127-132; M. Pietraszewski, Glosa, „Rejent”, 2010, nr 3, s. 211-230.

42 Wyrok niepublikowany.

43 B. Rakoczy, Skuteczność norm prawa kanonicznego w prawie polskim. Komentarz do tezy wyroku Sądu Apelacyjnego w Poznaniu z 26 maja 2011, „Monitor Prawny Proboszcza”, 2012, nr 9, s. 15. 
mieć również na uwadze kan. 1377: „Kto alienuje dobra kościelne bez przepisanego prawem zezwolenia, powinien być ukarany sprawiedliwą karą".

\section{c. Przeprowadzenie konsultacji z organami doradczymi}

Do ważności umowy dzierżawy należy również obowiązek uzyskania pisemnego zezwolenia od biskupa diecezjalnego. Biskup może udzielić stosownego zezwolenia dopiero po uzyskaniu zgody przez radę do spraw ekonomicznyc ${ }^{44} \mathrm{i}$ kolegium konsultorów ${ }^{45}$, oraz zainteresowanych osób ${ }^{46}$. Ma to zastosowanie wówczas, gdy wartość rzeczy alienowanej mieści się między najniższą i najwyższą sumą, określoną dla własnego kraju przez Konferencję Episkopatu $^{47}$, oraz przy podejmowaniu jakichkolwiek transakcji, na skutek których majątek osoby prawnej może się znaleźć w gorszej sytuacji ${ }^{48}$. W przypadku, gdy wartość rzeczy alienowanej przekracza najwyższą sumę określoną przez Konferencję Episkopatu lub gdy chodzi o rzeczy darowane Kościołowi na podstawie ślubu, a także rzeczy kosztowne z racji artystycznych i historycznych ${ }^{49}$, jak i relikwie świętych oraz rzeczy doznające wielkiej czci ze strony wiernych ${ }^{50}$, do ważności aktu konieczne jest zezwolenie Stolicy Apostolskiej. Uzyskanie zgody dwóch kolegiów i zainteresowanych osób jest instrumentem ochronnym, aby czynność prawna dokonana na majątku kościelnym była decyzją roztropną i nie budziła wątpliwości.

Biskup diecezjalny zobowiązany jest uzyskać zgodę od diecezjalnej rady ds. ekonomicznych. Zadaniem tej rady jest udzielenie fachowej oceny dotyczącej sytuacji ekonomicznej diecezji, służenie biskupowi radą w kwestii aktualnego zarządu dobrami oraz ukazywanie na przyszłość sposobów pokrycia potrzeb materialnych w diecezji ${ }^{51}$. W określonych sytuacjach biskup ma obo-

\footnotetext{
44 Kan. 492.

45 Kan. 502.

46 Kan. $1292 \$ 2$.

47 Kan. $1292 \$ 1$.

48 Kan. 1295.

49 Kan. $1292 \$ 2$.

so Kan. $1190 \$ 2$.
}

sז Szerzej zob. M. Sitarz, Kompetencje organów kolegialnych $w$ Kościele partykularnym, Lublin 2008, s. 63-65; J. Krukowski, Kolegialne organy konsultacyjne w Kościołach partykularnych, [w:] Struktury kolegialne w Kościele partykularnym. Materiaty z ogólnopolskiej konferencji naukowej zorganizowanej przez Stowarzyszenie Kanonistów Polskich, Wydziat Nauk 
wiązek wysłuchać opinii rady ds. ekonomicznych, natomiast w przypadku alienacji, jak i nadzwyczajnego zarządzania biskup diecezjalny zobowiązany jest uzyskać jej zgodę ${ }^{52}$. Warto również podkreślić, że biskup zobowiązany jest dostarczyć radzie ds. ekonomicznych wszelkich koniecznych informacji w celu kompetentnego i odpowiedzialnego zajęcia stanowiska, oraz do tego, by pozwolił radzie na swobodne wyartykułowanie poglądów w danej kwestii. Zatajenie istotnych informacji może powodować nieważność aktu i być podstawą skargi o unieważnienie lub rozwiązanie wyrokiem sędziego ${ }^{53}$. Obok zgody rady ds. ekonomicznych biskup diecezjalny zobowiązany jest uzyskać zgodę kolegium konsultorów. Podobnie jak rada ds. ekonomicznych, kolegium konsultorów jest organem obligatoryjnym ustanowionym przez biskupa diecezjalnego ${ }^{54}$. Zaniechanie przez biskupa tego obowiązku powoduje nielegalność aktu administracyjnego oraz sankcję nieważności lub niegodziwości aktu ${ }^{55}$.

Pojawia się jednak pytanie: dlaczego warunkiem udzielenia zgody przez biskupa diecezjalnego jest uprzednia zgoda dwóch organów, a nie tylko jednego? Według J. Krukowskiego podyktowane jest to przyjętymi kryteriami. Pierwszy organ rozpatruje w kryteriach ekonomicznych, drugi natomiast kieruje się kryteriami duszpasterskimi, jak pożytek lub konieczność przeprowadzenia transakcji dla dobra duchowego Kościoła ${ }^{56}$.

Zgodnie z kan. $127 \$ 1$ i 2 pkt 1: „Jeśli jest wymagana zgoda, akt przełożonego jest nieważny bez zwrócenia się o wyrażenie zgody przez te osoby albo podjęty wbrew ich zdaniu lub któregoś z nich”.

Prawnych TN KUL $i$ Wyższe Seminarium Duchowne w Tarnowie, red. J. Krukowski, T. Rozkrut, Tarnów 2004, s. 28-34; zob. A. Farrey, The Diocesan Finance Council. Functions and Duties According to the Code of Canon Law, „Studia Canonica”, 1989, nr 23, s. 149-166.

$52 \quad$ Kan. 1277; kan. $1292 \$ 1-2$; kan. 1295. Zob. F. Morrisey, Ordinary and Extraordinary Administration. Canon 1277, „The Jurist”, 1988, nr 48, s. 709-726.

s3 Kan. 125 i 126; por. M. Sitarz, Wady kościelnych aktów administracyjnych wynikające z pominięcia przez biskupa diecezjalnego opinii lub zgody kolegialnych organów konsultacyjnych, [w:] Struktury kolegialne w Kościele partykularnym..., dz. cyt., s. 143.

s4 Szerzej zob. M. Sitarz, Kolegium konsultorów w Kodeksie Prawa Kanonicznego z 1983 i w partykularnym prawie polskim, Lublin 1999.

"s J. Krukowski, Kolegium konsultorów. Struktura i kompetencje, [w:] Struktury kolegialne w Kościele partykularnym..., dz. cyt., s. 101; por. M Sitarz, Wady kościelnych aktów administracyjnych..., dz. cyt., s. 134.

s6 Tenże, Kolegium konsultorów. Nowy organ władzy w strukturze Kościoła partykularnego, „Studia Sandomierskie”, 1985-1989, nr 5, s. 25. 


\section{d. Zezwolenie Stolicy Apostolskiej}

Ma miejsce, gdy wartość alienowanych dóbr osoby prawnej podległej biskupowi diecezjalnemu przekracza sumę najwyższą (obecnie $1000000 €$ ) ustaloną przez Konferencję Episkopatu, lub gdy chodzi o rzeczy darowane Kościołowi na podstawie ślubu, a także o rzeczy kosztowne z racji artystycznych lub historycznych, jak i relikwie świętych oraz rzeczy doznające wielkiej czci ze strony wiernych. Biskup diecezjalny w takim przypadku zobowiązany jest, oprócz uzyskania zgody rady ds. ekonomicznych i kolegium konsultorów oraz zainteresowanych osób, uzyskać zgodę Stolicy Apostolskiej, a konkretnie Kongregacji ds. Duchowieństwa ${ }^{57}$.

\section{e. Wyszczególnienie części wcześniej alienowanych}

W przypadku, gdy rzecz alienowana jest podzielna, w prośbie o zezwolenie na alienację należy wymienić części wcześniej alienowane. Zgodnie z kan. 1292 $\$ 3$ niezachowanie tego wymogu skutkuje nieważnością udzielonego zezwolenia. Przedmiotowa regulacja ma na celu zapobieżenie stopniowemu alienowaniu rzeczy podzielnej i pomijaniu w ten sposób przewidzianego w procedurze alienacyjnej wymogu uzyskania stosownej zgody ${ }^{58}$. Rzecz podzielna, zdaniem T. Pawluka, stanowi jedność fizyczną, jak np. nieruchomość gruntowa ${ }^{59}$.

\subsection{Warunki umowy dzierżawy ad licitam}

Prawodawca obok warunków koniecznych wymaganych do ważności alienacji, do których należy zawarcie umowy dzierżawy, określił również warunki dotyczące godziwej alienacji. Są nimi:

\section{a. Słuszna przyczyna}

Przepis kan. $1293 \$ 1$ pkt 1 wymienia słuszną przyczynę, do której należy: „nagląca potrzeba, wyraźna korzyść pobożność, miłość lub inna poważna

57 Zob. art. 98, Ioannes Paulus PP. II, Constitutio apostolica Pastor Bonus, 28 VI 1988, AAS, R. 80, 1988, s. 841-912; Jan Paweł II, Konstytucja apostolska Pastor Bonus o Kurii Rzymskiej, [w:] Ustrój hierarchiczny Kościoła. Wybór źródet, red. W. Kacprzyk, M. Sitarz, Lublin 2006, s. 243.

${ }^{8}$ L. Świto, Alienacja majątku kościelnego $w$ diecezjach rzymskokatolickich $w$ Polsce, Olsztyn, s. 124.

59 T. Pawluk, Prawo kanoniczne wedtug Kodeksu Jana Pawła II, t. 4, Olsztyn 1990, s. 51. 
racja pasterska”. Rozumieć należy, że warunek ten winien być spełniony w przypadku, gdy wartość rzeczy alienowanej przekracza najniższą sumę wyznaczoną zgodnie z kan. $1292 \$ 1$. W literaturze kanonistycznej znaleźć można wiele takich przykładów, jednak nie należy ich traktować taksatywnie. Odnośnie do zawarcia umowy dzierżawy za słuszną przyczynę należy uznać takie okoliczności, jak: konieczność wybudowania domu parafialnego, konieczność spłaty długu ${ }^{60}$, czy też oczywistą korzyść kościelnej osoby prawnej.

\section{b. Wycena rzeczy alienowanej}

O tym stanowi kan. $1293 \$ 1$ pkt 2 , mówiący, że warunkiem godziwej alienacji jest uprzednie dokonanie wyceny rzeczy alienowanej. Wycena musi zostać dokonana przez rzeczoznawców, będących biegłymi w sztuce lub dziedzinie właściwej dla konkretnej ekspertyzy, których musi być przynajmniej dwóch i którzy swoją opinię winni wyrazić na piśmie. Forma pisemna, jak słusznie twierdzi L. Świto, służy nie tylko celom dowodowym, ale służy także jako motyw wzmacniający rzetelność biegłych ${ }^{61}$. Należy również podkreślić, że wymóg dokonania wyceny rzeczy alienowanej pozostaje w związku z treścią kan. $1294 \$ 1$, który stanowi, że „nie powinno się alienować rzeczy za sumę niższą niż ta, która została określona w wycenie”.

\section{c. Zakaz dzierżaw na rzecz zarządców i ich krewnych}

Zasadą Kościoła jest zakaz wydzierżawiania dóbr kościelnych ich zarządcom albo krewnym lub powinowatym zarządców, aż do czwartego stopnia ${ }^{62}$, chyba że rzecz wydzierżawiana byłaby małej wartości ${ }^{63}$. Należy podkreślić, że w jednym i w drugim przypadku do godziwości alienacji wymagane jest pisemne zezwolenie kompetentnej władzy. W przypadku zarządców podlegających władzy biskupa diecezjalnego władzą tą jest sam biskup, natomiast w przypadku dóbr diecezjalnych, których zarządcą jest sam biskup, kompetentną władzą do wydania zezwolenia będzie Stolica Apostolska ${ }^{64}$.

6o W. Wójcik, Księga V. Dobra doczesne Kościoła, [w:] W. Wójcik, J. Kukowski, F. Lempa, Księga V. Dobra doczesne Kościoła. Księga VI. Sankcje w Kościele, t. 4, Lublin 1987, s. 90.

${ }_{6} \quad$ L. Świto, Alienacja majątku kościelnego..., dz. cyt., s. 125.

62 Sposób liczenia stopni pokrewieństwa określa kan. $108 \$ 1-3$.

63 Kan. 1298.

${ }^{64}$ L. Świto, Alienacja majątku kościelnego..., dz. cyt., s. 127. 


\section{d. Zachowanie innych środków ostrożności}

Zgodnie z kan. $1293 \$ 2$ do kompetentnej władzy kościelnej należy określić zachowanie innych środków ostrożności. Prawodawca powszechny daje możliwość biskupom diecezjalnym, aby dostosowali je do warunków lokalnych oraz do aktualnej sytuacji społeczno-gospodarczej diecezji. Dla przykładu można wymienić: czas trwania dzierżawy, godziwy cel przeznaczenia dzierżawy, zabezpieczenie przed arbitralnym dysponowaniem gruntem przez dzierżawcę.

\section{Umowa dzierżawy w wybranych synodach diecezjalnych}

Analiza prawa partykularnego zawartego w synodach diecezjalnych w Polsce stanowi uszczegółowienie prawa powszechnego oraz dostosowanie prawa kanonicznego do warunków społeczno-gospodarczych. Prawo partykularne uchwalone na synodach jest również praktyczną aplikacją prawa powszechnego, może także stanowić rodzaj „instrukcji”, jak stosować prawo kanoniczne w praktyce. Mając na uwadze aktualność zagadnienia, poniżej zostaną zaprezentowane trzy ostatnie synody diecezjalne ${ }^{65}$, do których należą: Synod Diecezji Kaliskiej (2009), Synod Diecezji Toruńskiej (2011), Synod Archidiecezji Warmińskiej (2012).

\section{1 .}

Według Pierwszego Synodu Diecezji Kaliskiej ${ }^{66}$ przy zawieraniu umów dzierżawy należy kierować się przepisami odnoszącymi się do umów dzierżawy gruntu ${ }^{67}$. Umowa taka powinna być sporządzona na piśmie pomiędzy parafią, którą reprezentuje proboszcz (administrator), i dzierżawcą, z datą i podpisami stron. W umowie należy wyszczególnić powierzchnię gruntu,

65 Zakres dzierżawy w polskich synodach diecezjalnych w latach 1983-2009 został już opracowany przez takich autorów, jak: S. Dubiel, Uprawnienia majątkowe Kościoła Katolickiego w Polsce w świetle Kodeksu Prawa Kanonicznego z 1983 roku, Konkordatu z 1993 roku i ustaw synodalnych, Lublin 2007; P. Kaleta, Zadania zarządcy majątku kościelnego w Kodeksie Prawa Kanonicznego z 1983 roku i w polskich synodach diecezjalnych, Lublin 2012.

${ }_{6}$ Pierwszy Synod Diecezji Kaliskiej 2007-2009. Prawo diecezjalne Kościoła Kaliskiego, Kalisz 2009 [dalej: KAL].

${ }^{67}$ Statut 705, [w:] KAL, s. 135. 
klasę ziemi oraz położenie gruntu, wysokość dzierżawy, czas trwania dzierżawy (w zasadzie 5 lat), zabezpieczenie przed arbitralnym dysponowaniem gruntem przez dzierżawcę, warunki dalszego ewentualnego przedłużenia dzierżawy. Przy ustalaniu dzierżawnego należy brać pod uwagę klasę zie$\mathrm{mi}$, stosowane $\mathrm{w}$ regionie stawki dzierżawne oraz inne specyficzne czynniki, jak: popyt na ziemię, szczególnie jej przeznaczenie. Tekst umowy dzierżawy powinien być sporządzony w trzech egzemplarzach podpisanych przez wydzierżawiającego, dzierżawcę i przedstawiciela rady parafialnej. Umowę należy przedstawić Kurii do potwierdzenia. Po potwierdzeniu nabiera ona mocy wiążącej ${ }^{68}$.

W dalszej części instrukcji prawodawca kaliski określa przeznaczenie zysków z tytułu dzierżawy. Dochód z dzierżawy gruntów, których powierzchnia nie przekracza 5 ha należy do beneficium proboszczowskiego; w przypadku, gdy przekracza 5 ha, dochód jest dzielony na dwie części: część gruntów równoważna 5 ha należy do beneficium proboszczowskiego, reszta winna być przeznaczona w całości na renowację, remont, konserwację budynków parafialnych ${ }^{69}$. W ciągu miesiąca, po upływie roku dzierżawnego, proboszcz przedstawia Kurii Diecezjalnej na piśmie rozliczenie wpływów z dzierżawy, gdy powierzchnia gruntu przekracza 5 ha. Rozliczenie winno być podpisane przez proboszcza i przedstawiciela rady parafialnej ${ }^{70}$.

\section{2 .}

Zgodnie z Pierwszym Synodem Diecezji Toruńskiej ${ }^{71}$, w zakresie dzierżawy prawodawca toruński wydał szczegółową instrukcję o wydzierżawieniu, wynajmie i użyczeniu parafialnych obiektów i nieruchomości, w której określił, że w celu wydzierżawienia obiektów parafialnych wymagana jest zgoda biskupa diecezjalnego pod rygorem bezskuteczności umowy. Wymaganą zgodę zarządca majątku kościelnego winien uzyskać przed zawarciem umowy

68 Umowa dzierżawna dotycząca gruntów parafialnych obowiazująca w Diecezji Kaliskiej od 1 grudnia 2006 roku, [w:] KAL, s. 289-290.

69 Statut 705, [w:] KAL, s. 135.

70 Umowa dzierżawna dotycząca gruntów parafialnych..., dz. cyt., s. 291.

${ }_{71}$ Uchwaty Pierwszego Synodu Diecezji Toruńskiej. Prawo partykularne Kościoła Toruńskiego, Toruń 2011 [dalej: TOR]. 
dzierżawy. Do wniosku o wyrażenie zgody przez biskupa diecezjalnego zarządca winien załączyć projekt umowy w dwóch egzemplarzach zawierający wszystkie postanowienia. Dopiero po otrzymaniu zgody należy przygotować umowę w czterech jednobrzmiących egzemplarzach i przedstawić ją w Kurii Diecezjalnej w celu stwierdzenia jej zgodności z projektem, na który otrzymano zgodę. Jeden egzemplarz umowy pozostaje w archiwum Kurii Diecezjalnej, natomiast trzy pozostałe, zaopatrzone w stosowną adnotację Kurii, przekazuje się proboszczowi z przeznaczeniem dla parafii, partnera umowy i urzędu gminy ${ }^{72}$. W przypadku przedłużenia umowy lub wprowadzenia do niej zmian prawodawca wymaga ponownego zatwierdzenia przez Kurię Diecezjalną ${ }^{73}$.

W dalszej części instrukcji biskup toruński określa, co należy zamieścić w umowie dzierżawy: wydzierżawiającego i dzierżawcę, przedmiot dzierżawy, pożytki pobierane przez dzierżawcę wraz ze szczegółowym ich wykazem, zobowiązanie dzierżawcy do uprawy roli ze starannością dobrego gospodarza oraz strzeżenia jej granic, wysokość rocznego czynszu dzierżawy oraz płacącego należności podatkowe do Skarbu Państwa lub gminy, termin płatności czynszu (dopuszcza się płatność najwyżej w dwóch ratach) ${ }^{74}$, okres dzierżawy oraz warunki wygaśnięcia lub rozwiązania umowy, zasadę oddawania przez dzierżawcę wydzierżawionego przez siebie gruntu osobie trzeciej w jakiekolwiek używanie lub poddzierżawienie oraz inne warunki umowy, jak np. ponoszenie kosztów umowy ${ }^{75}$.

W zakresie rozliczenia umowy dzierżawy proboszcz każdorazowo zobowiązany jest wydać dzierżawcy pisemne pokwitowanie otrzymanej kwoty za dzierżawę, wpisując ją do parafialnej księgi rachunkowej. Kopię pokwitowania dostarcza Kurii Diecezjalnej, która na tej podstawie pobiera 50 proc. od otrzymanej kwoty na cele ogólnodiecezjalne, natomiast po otrzymaniu pierwszej raty czynszu proboszcz zwraca Kurii Diecezjalnej poniesione przez

${ }_{72}$ Instrukcja o wydzierżawieniu, wynajmie i użyciu parafialnych obiektów i nieruchomości, [w:] TOR, s. 418.

73 Tamże, pkt $2 \$ 4$, s. 418.

74 Zob. art. 699 k.c. Ponieważ przyjmuje się, że środki na ten cel dzierżawca uzyskuje z pobranych już pożytków. Zob. Z. Radwański, J. Panowicz-Lipska, Zobowiazania..., s. 158.

75 Tamże, pkt $5 \$ 1$. 
nią nakłady, a pozostałe kwoty czynszu przechowuje na bankowym koncie parafii $^{76}$.

Prawodawca toruński określił, że dochody z dzierżawy należy przeznaczyć przede wszystkim na remont obiektów parafialnych, nowe inwestycje parafii, renowacje lub zakup sprzętu kościelnego, zaopiniowane przez parafialną radę gospodarczą. Wydatki na utrzymanie proboszcza i pracowników kościelnych oraz funkcjonowanie plebanii pokrywa się z tych dochodów jedynie w wypadku konieczności, wpisując je do parafialnej księgi rachunkowej ${ }^{77}$.

\section{3.}

I Synod Archidiecezji Warmińskiej ${ }^{78}$ odnośnie do dzierżawy stanowi, że umowy dzierżawne wymagają pisemnej zgody Arcybiskupa Warmińskiego. Kopię zaktualizowanej umowy należy przedstawić w Wydziale Ekonomicznym Kuriii ${ }^{79}$. Szczegółowe regulacje prawodawca warmiński zawarł w Dekrecie ustalajacym wykaz czynności prawnych przekraczajacych granice i sposób zwyczajnego zarządzania kościelnych publicznych osób prawnych podlegających arcybiskupowi warmińskiemu ${ }^{80}$.

Dzierżawa należy do aktów nadzwyczajnego zarządzania, natomiast do ważności takiego aktu wymagana jest zgoda ordynariusza miejsca ${ }^{81}$. Do tych aktów należy dodać: oddanie nieruchomości w użytkowanie bezczynszowe, korzystanie z nieruchomości rolnej (tzw. dzierżawa za podatek) oraz użyczenie. Przed zawarciem umowy dzierżawy należy pisemnie poinformować ordynariusza miejsca ${ }^{82}$. Odnośnie do otrzymywania dochodów z tytułu dzierżawy prawodawca warmiński zaleca, aby część otrzymanej kwoty - wskazanej przez ordynariusza miejsca - przekazać na rzecz Archi-

\footnotetext{
${ }_{76}$ Tamże, pkt $6 \$ 1-3$.

77 Tamże, pkt $6 \$ 4$.

${ }^{78}$ I (XIV) Synodu Archidiecezji Warmińskiej 2006-2012. Misja Kościoła Warmińskiego w dziele Nowej Ewangelizacji, Olsztyn 2012 [dalej: WAR].

79 Statut 451, [w:] WAR, s. 104.

so L.dz. 114/2012.

8I Dekret ustalający wykaz czynności prawnych przekraczajacych granicę i sposób zwyczajnego zarządzania kościelnych publicznych osób prawnych podlegających arcybiskupowi warmińskiemu, [w:] WAR, pkt 1 d, s. 215.

82 Tamże, pkt. 2, s. 215.
} 
diecezji Warmińskiej. Umowa ta winna być zawarta na piśmie, jeśli grunty są dzierżawione albo oddane w bezczynszowe używanie gruntu i pobieranie pożytków (tzw. dzierżawa za podatek) i, jeśli to możliwe, należy tak określić warunki, aby grunty parafialne przynosiły parafii dochód, np. w formie czynszu dzierżawnego ${ }^{83}$.

\section{Wnioski}

Podsumowując przedstawione powyżej rozważania z zakresu prawa kanonicznego i prawa partykularnego, można przedstawić w następujące tezy, wynikające zarówno z doktryny, jak i dyscypliny kościelnej odnośnie do zawarcia umowy dzierżawy:

1. Dzierżawa należy do aktów nadzwyczajnego zarządzania; przy zawieraniu umów należy zastosować przepisy z alienacją sensu largo kan. 1292-1294.

2. Z uwagi na fakt, że Konferencja Episkopatu nie określiła norm, które akty należy zaliczyć do nadzwyczajnego zarządzania, w nawiązaniu do kan. 1297 należy zachować prawo statutowe kościelnej osoby prawnej, a w razie gdyby takowego nie było - prawo partykularne ustanowione przez biskupa diecezjalnego dla podległych jego władzy kościelnych osób prawnych.

3. Do ważności zawartej umowy dzierżawy należy zachować prawo państwowe, tj. art. 693-709 k.c. oraz zachować prawo kanoniczne kan. 1292 $\$ 1$ określający uzyskanie uprzedniego zezwolenia kompetentnej władzy, w przypadku gdy wartość dzierżawy przekracza sumę najwyższą (obecnie $1000000 €$ ), lub gdy chodzi o rzeczy darowane Kościołowi na podstawie ślubu, a także o rzeczy kosztowne z racji artystycznych lub historycznych, oprócz zezwolenia biskupa diecezjalnego wymagana jest zgoda Stolicy Apostolskiej, tj. Kongregacji ds. Duchowieństwa. W przypadku, gdy alienowana rzecz jest podzielna, w prośbie o zezwolenie na alienację należy wymienić części wcześniej alienowane.

4. Do godziwości czynności prawnej należy: wskazać słuszną przyczynę, wycenę rzeczy alienowanej, wskazać osobę dzierżawcy i jego pokrewieństwo z zarządcą majątku kościelnego oraz zachować inne środki ostrożności, jak np. czas trwania dzierżawy czy sposób odstąpienia od dzierżawy.

\footnotetext{
${ }_{3}$ Zarzadzenia o gruntach rolnych, [w:] WAR, pkt 2, s. 413.
} 
5. Zarówno prawo powszechne, jak i partykularne nie określa minimalnego, jak i maksymalnego czasu trwania umowy dzierżawy. To może skutkować arbitralnością zawierania umowy dzierżawy. Przesłanka ta stanowi postulat de lege ferenda.

6. W prawie kanonicznym brak wzmianki odnośnie do ustania umowy dzierżawy, jak i sposobu jej wypowiedzenia. W takim przypadku wydaje się słuszne przyjąć postanowienia art. 673 i 704 k.c.

7. Prawo partykularne nie określa jednolitego systemu płatności z tytułu dzierżawy, stąd wskazane jest stworzenie nowych jednolitych rozwiązań prawnych, ułatwiających praktyczne wykorzystanie tej formy zagospodarowania gruntów.

8. Analizowane statuty synodów diecezjalnych nie określają konsekwencji związanych z zaleganiem z opłatą za czynsz, w związku z tym wydaje się słuszne, by zastosować tu art. 672 k.c.

9. W warunkach umowy dzierżawy brak zapisu, że dzierżawca ma dbać o należyty stan przedmiotu dzierżawionego, przeprowadzać na własny koszt ewentualne naprawy niezbędne do zachowania przedmiotu dzierżawy, i że po jej zakończeniu winien oddać przedmiot dzierżawy w takim stanie, w jakim przyjął do dzierżawy (art. 697 k.c.).

10 . W przedstawionym prawie partykularnym zniknął zapis stanu pokrewieństwa i powinowactwa dzierżawcy wobec zarządcy majątku kościelnego, co jest naruszeniem kan. 1298.

11. Przedstawione prawo partykularne nie odwołuje się do prawa cywilnego. Według obowiązujących przepisów prawa podatkowego, dochody (a nie przychody!) z tytułu dzierżawy nieruchomości podlegają opodatkowaniu podatkiem od osób prawnych. Na kościelnej osobie prawnej spoczywa więc obowiązek prowadzenia ewidencji rachunkowej oraz wydatkowej. W przypadku, gdy dochód z tytułu dzierżawy nieruchomości nie został przeznaczony na cele statutowe lub inne cele określone w art. 17 ust. 1 pkt $4 \mathrm{a}$ lit. b ustawy o podatku dochodowym od osób prawnych, kościelna osoba prawna zobowiązana jest do odprowadzenia podatku od działalności gospodarczej oraz dokonywania wpłat zaliczek na podatek dochodowy oraz złożenia zeznania rocznego CIT-8 do końca trzeciego miesiąca roku następnego. 


\title{
The Rules of Lease Agreement in the Code of Canon Law 1983
}

\author{
Summary
}

Leasing is one way of managing wasteland belonging to the ecclesiastical juridical person. The equivalent of this contract is the payment of rent to lessor. Cannon Law uses regulations connecting with alienation (cc. 1291-1294) to protect the ecclesiastical goods belonging to the juridical person, from the risk of a worse economic condition. The Polish Bishops' Conference has not developed appropriate standards in connection with cc. 1297, therefore the statutory ecclesiastical right of the juridical person should be retained, in the event of their absence, the particular law established by the diocesan bishop allows for those subordinate to the Church, the power of corporation.

The validity of the lease agreement should include: To observe the civil law in the given country, to obtain the written consent of the relevant authority prior to procedures,

in event of alienated goods being divisible, the request for permission for alienation must mention goods previously alienated. The fairness of legal actions includes: to identify a legitimate cause, the valuation of goods alienated, to identify the tenant and his relationship with the administrator of church property and undertake other precautions such as the duration or withdrawal from the lease.

Kewords: canon law, lease, alienation, particular law, temporal goods 
